\title{
The Implementation of The Land Right Transfer Registration According to Letter Citation in Jatibogor Village, Suradadi - Tegal
}

\begin{abstract}
Ahmad Tsekhudin ${ }^{1}$ and Umar Ma'aruf ${ }^{2}$
Abstract. According to the certainty on the material law, the definition of transfer of land right is the transfer of old owner to the new one. There are 2 (two) ways of the transfer of land right, which are to transfer and being transferred. To transfer means the transfer of land right without any legal action done by the owner, for example by the hereditarily. While being transferred refers to the transfer of the land through the legal action by the owner, for example by the purchase and sale. According to Paragraph 37 Article 1 Government Regulation Number 24 the Of 1997, it is stated that the Transfer of land right done by making the deed by Land Titles Registrar, so the transfer deed of land transfer will have a strong proof as a deed in the court system and a deed as the base of issuing the ownership certificate. The registration of the land as Government Regulation Number 24 the Of 1997 aims to give the legal certainty and legal protection to the right holder of the land, apartment units and other registered rights so it can easily prove that himself/herself is the right holder. On the other hand, we also acknowledge the registration of land tax, such as pipil-girik, petok, letter C, which is done by the Tax Office in Java Island. Due to there are still some lands in Indonesia that aren't registered yet around society.

Keywords: The Transfer of A Land Right; Registration; Letter D
\end{abstract}

\section{Introduction}

The land, in a legal definition, is an earth's surface as stated on Paragraph of Acts Number 5 the Of 1960 about Agrarian Principles. ${ }^{3}$ According to the Indonesia Dictionary, the land is: An earth's surface or the upper layer of the earth; The earth's surface that is given the limitation; The land; and The materials of earth, earth as a material (sand, rocky ground, rocks and so on $)^{4}$

The relation between human and earth has existed since the existence of human being. How important a land is for a human being can be seen by its philosophical principles, which the human is created by Allah the Almighty God from the earth, ${ }^{5}$ live (consume) from the earth and after death will return to the earth. All Samawi religions state that the first human is Prophet Adam AS was created from the earth. ${ }^{6}$ That is why the role of the earth is significant for human's life and living. Human being and the earth is the thing cannot be separated. To fulfill their livelihoods, such as housing, places to do agriculture activities and even the places to the burial, a human being always relates to the earth. So the earth has an important role in human's life. ${ }^{7}$

\footnotetext{
${ }^{1}$ Master of Notary's Student Sultan Agung Islamic University (UNISSULA) Semarang email ahmadtsekhudin@gmail.com

2 Lecturer of the Faculty of Law UNISSULA Semarang Indonesia.

3 Van Dijk 2006 Pengantar Hukum Adat Indonesia Translated by Mr. A. Soehadi. Publisher: Mandar Maju Bandung page 66.

${ }^{4}$ See Pusat Bahasa Depdiknas 2003 Kamus Besar Bahasa Indonesia Balai Pustaka Jakarta page 1132.

5 Umar Ma'aruf 2014 Hak Menguasai Negara Atas Tanah \& Asas-Asas Hukum Pertanahan Semarang Unissula Press page 2.

${ }^{6}$ Ibid

${ }^{7}$ Rosnidar Sembiring 2017 Hukum Pertanahan Adat Depok Rajawali Pers Page 4
} 
The earth is a symbol of social status as well where the ownership of a land symbolizes the value of honor, pride and self-achievement so economically, socially and culturally, the land has become a source of living, a symbol of identity. The land issue for human being always exists due to it has the most important meaning to the human's living and life since the land isn't just a place to live but also to farm, traffic lane, agreements and in the end a place of burial. ${ }^{8}$ To create the legal certainty and legal protection of the land right, it needs the land registration, which is by the issue of Government Regulation Number 24 the Of 1997 about the land registration.

According to the Law, the right transfer of a land can be done by the process of deed issue for purchase and sale deed, deed of inheritance or deed of grant signed by all authorized parties in front of Land Title Registrar, so the deed of the right transfer of a land will have strong proof as a deed in the court system and the deed as the issuing principle of ownership deed. The usual things happen in Indonesia is the transfer process of a land is done in front of the village officials/ the headman and done without an authentic process in front of Land Title Registrar so they don't have any legal proof related to the land ownership. Another issue can be seen just after the transfer done, it isn't registered directly to the National Land Agency as stated on Government Regulation Number 24 the Of 1997 about the Land Registration aims to achieve the legal certainty for both physically and juridical related of the right of the land.

On the other hand, we know the matter of the registration of tax land, such as pipil-girik, petok, letter $\mathrm{C}$, which is done by the Tax Offices in Java Island. ${ }^{9}$ That is the reason why there is still numerous land in Indonesia are unregistered yet as regulated by the government. There are various letters written by village officials to create a written proof of a land without fulfilling the procedure of Government Regulation Number 24 the Of 1997. Those lands aren't converted yet, controlled by the State and occupied by people accidentally or regulated by the headman and recognized by village officials as if those lands are the rights of individual or in the category of tradition rights. ${ }^{10}$

According to those issues, the writer found the ones related to the transfer process of the land right that has been issued for so long (for years) with underhand certificate (sealed), and witnessed by village officials or the headman that furthermore the transfer will be written on the citation of Letter $\mathrm{C}$ book of the village and the unregistered right in local Land Affair Office. It doesn't meet the requirement of Government Regulation Number 24 the Of 1997 about the land registration aims to give the legal certainty and legal protection to the right holder of a certain land. That is why the writer tried to do the study using Sociological Juridical about the implementation of the right transfer of a land on the ownership registration of a land according to the citation of Letter D in Jatibogor Village, Suradadi Subdistrict, Tegal Regency.

According to the background above, so the formulation of the problem about how the transfer procedure of the land right, which is at the beginning is on Letter D citation, until got certified and the obstacles while doing implementation the transfer of land right, which is on Letter D citation, becomes ownership deed in Jatibogor Village, Suradadi Subdistrict, Tegal Regency.

\section{Research Method}

This research is written according to the Sociological Juridical approach, which is by using

\footnotetext{
${ }^{8}$ http://skripsitesishaeran.blogspot.co.id

${ }^{9}$ Dr Urip Santoso 2016 Pendaftaran dan Peralihan hak atas tanah Kencana Jakarta

${ }^{10}$ Andy Hartanto 2014. Karakteristik Jual Beli Tanah yang Belum Terdaftar Hak atas Tanahnya Laksbang Justitia Surabaya page
} 
the methods that see the reality in the field, especially in the transfer of the land right to ownership registration of a land according to the citation of Letter $D$ of the Village.

The types and sources of research data are the following: Primary data, including the interview data, field observation, and data of the informants. While secondary data are including primary legal materials, which are the binding legal materials, contain of Acts Number 5 the Of 1960 about the Regulation of Agrarian Principles, Government Regulation Number 24 the Of 1997 about the Land Registration, Government Regulation of Agrarian/ Head of Land Affairs Board Number 8 the Of 2012 about the Alteration of the Regulation of Head of National Land Affairs Board of Republic of Indonesia Number 3 the Of 1997 about the certainty of implementation of Government Regulation 24 the Of 1997 about the Land Registration. The Secondary Legal Materials are the legal materials from the library research, including literature, legal journal and legal magazines, papers, legal seminars, magazines and newspapers, thesis, scientific articles, expert opinions, various relevant books with the explanation about the procedure of the transfer implementation of the land right. The tertiary legal materials, the legal materials that support the primary and secondary legal materials, such as e-articles (internet).

\section{Result And Discussion}

\subsection{How is the Implementation of Transfer Procedure of the Land Right from the Citation of Letter D to Get the Certificate in Jatibogor Village, Suradadi- Tegal}

The transfer of land right is the transfer of old owner to the new one. There are 2 (two) ways of the transfer of land right, which are to transfer and being transferred. To transfer means the transfer of land right without any legal action done by the owner, for example by the hereditarily. ${ }^{11}$ While being transferred refers to the transfer of the land through the legal action by the owner, for example by the purchase and sale, gift and exchange. ${ }^{12}$ According to the Tradition Law, the land purchase and sale is a legal activity where the seller gives the land over to buyer forever at the time the buyer is giving payment as the land's price to the seller, although the buyer just pays for a half of the total price. Thus, since this transaction happens, the land right has been transferred from the seller to the buyer, which means the buyer has got the ownership right of the land since. To guarantee that there are no violations of this activity, so it should be done in front of the Village Head (the Head Man), and society has to accept the legality. ${ }^{13}$

The transfer that is done in front of the village officials will be written on the book of Letter $C$ Village if the full payment has been done and the buyer will be given the copy so-called Letter $\mathrm{D}$ (petok) to be the base for issuing the ownership deed. The society generally understands the registration of ownership deed registration is by using the deed written by the Land Titles Registrar as the basis of issuing the deed but the reality is the deed issue doesn't use the one written by the Land Titles Registrar but petok issued before 1993. The land transfer before 1993 was due to the decision of Direktur Jenderal Pajak aged 27 March 1997 Number: SE-15/PJ.G/1993 about the prohibition of issuing girik/petuk D/Kekitir/Surat Objek Pajak (KP.PBB II). Due to this decision, people stopped the transfer using the old Number $C$ Village to the new Number $C$ Village after that regulation was

${ }^{11}$ L \& J A Law Firm 2013 Kiat dan Prosedur Mengurus Dokumen Tanah dan Bangunan Jakarta Nera Pustaka page 7

12 Anastasiasihombing.blogspot.co.id/2015/03/peralihan-hak-atas-tanah.html accessed on March 2018.

13 Ibid 
valid.

\subsection{How are the Obstacles of Transfer Implementation of Land Right, Which is Letter D Becomes Ownership Certificate in Jatibogor Village, Suradadi-Tegal}

The obstacles appear from the underhand transfer of land right witnessed by the village officials are:

- The sensitive issue of boundary dispute or ownership due to if the seller passed away so the heir will demand the right of the heir.

- The document forgery, which is to manipulate the existing documents to avoid the tax of BPHTB and PPh in process of deed issue.

- The boundary of the land isn't appropriate to that is written on Letter $D$ with the real measurement from the Land Affairs Office.

- The domination of the Headman to manipulate the ownership and the wide of the land.

So, in the registration of deed issue will constrain and won't get the legal certainty and legal protection. ${ }^{14}$

\section{Conclusion}

- The transfer done by people is constant, real and honest. So to guarantee there are no violations of the implementation of the transfer of land right, so the land transfer needs to be done in front of The Headman (Village Official), and society accepts the validity (as long as it meets the elements of agreed, capable, for the lawful, rights and responsibility (1320 Books of Material Law)) that after the transfer is done will be written on the book Letter C Village as the follow up to register the land according to the Government Regulation Number 24 the Of 1997 to achieve the legal certainty and legal protection to the land.

- The tortuous land transfer isn't registered directly for the issue of the ownership deed, which is very easy to be disputed physically or juristically.

\section{References}

[1] Van Dijk, 2006, Pengantar Hukum Adat Indonesia, Translation by Mr A.Soehadi, Publisher Mandar Maju, Bandung.

[2] See Pusat Bahasa Depdiknas, 2003, Kamus Besar Bahasa Indonesia, Balai Pustaka, Jakarta.

[3] Umar Ma'aruf, 2014, Hak Menguasai Negara Atas Tanah \& Asas - Asas Hukum Pertanahan, Semarang, Unissula Press.

[4] Rosnidar Sembiring, 2017, Hukum Pertanahan Adat, Depok, Rajawali Pers.

[5] http://skripsitesishaeran.blogspot.co.id.

[6] Andy Hartanto, 2014, Karakteristik Jual Beli Tanah yang Belum Terdaftar Hak atas Tanahnya, Laksbang Justitia, Surabaya.

[7] Anastasiasihombing.blogspot.co.id/2015/03/peralihan-hak-atas-tanah.html, accessed on March 2018.

[8] Acts Number 5 the Of 1960 about the Regulation of Agrarian Principles.

[9] Government Regulation Number 24 the Of 1997 about the Land Registration.

[10] Government Registration of Agrarian/ Head of Land Affairs Board Number 8 the Of 2012 about the Amendment of the Regulation of the Head of National Land Affairs Board of Republic of Indonesia Number 3 the Of 1997 about the Requirements of Implementation of Government Regulation Number 24 the Of 1997 about the Land Registration.

${ }^{14}$ Eva Interview The Counter Officer of Land Affairs Office Tegal Regency in Slawi 09 July 2018 